\title{
KEKUATAN DAN KELEMAHAN PELAYANAN KESEHATAN HAJI PADA DINAS KESEHATAN KABUPATEN MAMUJU
}

\section{Power and Health Service Wealth Hajj in Health Department of Mamuju District}

\author{
Andi Nasir, Agus Erwin \\ Jurusan Keperawatan Poltekkes Kemenkes Mamuju \\ (andinasir78@gmail.com) \\ (agus_risma05@yahoo.co.id)
}

\begin{abstract}
ABSTRAK
Tenaga kesehatan yang memberikan pelayanan kesehatan haji di Kabupaten Mamuju masih sulit mengoptimalkan penerapan standar, adanyaketerbatasan pemeriksaan haji, aspek kualitas dan kuantitas petugas pelayanan kesehatan haji serta minimnya ketersediaan anggaran pelayanan kesehatan haji. Penelitian ini bertujuanmengetahui kekuatan dan kelemahan Pelayanan Kesehatan Haji pada Kabupaten Mamuju. Jenis Penelitian ini adalah penelitian kualitatif pendekatan fenomenologis yang dilaksanakan pada Dinas Kesehatan dan Puskesmas Binanga Kabupaten Mamuju. Informan penelitian adalah penanggung jawab pelayanan kesehatan haji. Pengumpulan data menggunakan wawancara mendalam pada informan.Analisis data penelitian dilakukan secara deskriptif, observasi dan telaah dokumen. Hasil penelitian menunjukkan kekuatan pelayanan kesehatan haji adalah petunjuk teknis pelayanan kesehatan haji, prosedur pemeriksaan dan penentuan kelaikan sehat, surat keputusan panitia pemeriksa kesehatan haji, pelatihan kesehatan haji, ketersediaan insentif, ruangan pemeriksaan kesehatan haji dan peralatan pemeriksaan kesehatan haji, sedangkan kelemahan pelayanan kesehatan haji yaitu sosialisasi standar pelayanan kesehatan haji, pelaksanaan SOP tidak optimal, masih rendahnya kualitas dan kuantitas pengelola kesehatan haji, minimnya biaya operasional dan kurang optimalnya penginputan data jemaah sistem online (SISKOHAT), serta adanya keterbatasan ruang tes kebugaran.
\end{abstract}

Kata Kunci : Kekuatan, kelemahan, pelayanan kesehatan haji

\section{ABSTRACT}

Health workers who provide Hajj health services in Mamuju Regency are still difficult to optimize the implementation of standards, the limitation of hajj examination, quality and quantity aspects of Hajj health service workers and the minimum availability of Hajj health service budgets.This study aims to determine the strengths and weaknesses of Haj Health Services in MamujuDistrict.Type This research is a qualitative research phenomenological approach that is implemented at the Health Office and Binanga Public Health Center MamujuDistrict.The research informant is responsible for Hajj health services. Data collection used in-depth interviews with informants.Analysis of research data is done descriptively, observation and document review.The results of the study show that the strength of Hajj health services is technical guidance of Hajj health service, examination procedure and healthy skill determination, decision of haj pilgrim health committee, Hajj health training, incentive availability, Haj examination room and Hajj health inspection equipment, namely the socialization of standard Hajj health services, the implementation of SOP is not optimal, the low quality and quantity of Hajj health managers, the lack of operational costs and less optimal data entry system pilgrims online (SISKOHAT), and the limitations of the fitness test room.

Keywords : Strengths, weakness, health care hajj 


\section{PENDAHULUAN}

Pelayanan kesehatan calon haji adalah upaya kesehatan dalam meningkatkan kondisi fisik dan mental calon jema'ah haji dan pihak penyelenggara, untuk menyesuaikan diri terhadap lingkungan matra yang berubah secara bermakna, mulai dari penyiapan calon haji sampai dengan 2 minggu setelah tiba. ${ }^{1}$

Penyelenggaraan kesehatan haji merupakan upaya untuk meningkatkan kondisi terhadap pemeriksaan kesehatan, pembinaan kesehatan, pengendalian faktor resiko kesehatan dan standar pelayanan kesehatan haji di puskesmas untuk mendapatkan data kesehatan, perawatan, pemeliharaan, pembinaan dan perlindungan. ${ }^{2}$ Berbagai permasalahan yang memungkingkan muncul melalui faktor lingkungan internal dan eksternal ini kemudian di analisis sehingga diketahui apa yang menjadi kekuatan dan kelemahan (faktor internal) serta peluang dan ancaman (faktor eksternal) pelayanan kesehatan haji. Proses pengambilan keputusan strategis selalu berkaitan dengan pengembangan misi, tujuan, strategi, dan kebijakan perusahaan. Dengan demikian perencana strategis (strategy planner) harus menganalisis faktor-faktor strategis perusahaan (kekuatan, kelemahan, peluang dan ancaman) dalam kondisi yang ada saat ini.

Pelayanan Kesehatan Haji sangat membutuhkan sentuhan Pemerintah setempat melalui Dinas Kesehatan dan Puskesmas Kabupaten Mamuju dalam bentuk kebijakan sentral yang berpijak dalam menunjang peningkatan pelayanan kesehatan haji. Sehingga melalui beberapa permasalahan tersebut diatas, maka peneliti tertarik untuk melakukan analisis faktor internal (kekuatan dan kelemahan) Pelayanan Kesehatan Haji pada Dinas Kesehatan di Kabupaten Mamuju.

\section{METODE PENELITIAN}

Jenis penelitian yang digunakan dalam penelitian ini adalah penelitian kualitatif dengan menggunakan pendekatan fenomenologis. Informan penelitian terdiri dari sekretaris dinas, kepala bidang P2PL, kepala seksi P2, kepala sub bagian perencanaan, pengelola imunisasi, pengelola SISKOHAT, dokter pemeriksa haji, perawat pengelola haji, tenaga laboratorium, staf pelaporan haji, staf administrasi, dan tenaga pelatih senam kebugaran. Teknik pengumpulan data dilakukan dengan wawancara mendalam, observasi dan telaah beberapa dokumen untuk mengumpulkan data yang objektif dari informan pada Dinas Kesehatan Kabupaten Mamuju dan Puskesmas Binanga mengenai pelayanan dan pemeriksaan kesehatan.

Analisis pada data yang diperoleh akan dilakukan secara deskriptif. Data di analisis dengan menggambarkan kelompok faktor internal dan kelompok factor eksternal berdasarkan variabel penelitian.

\section{HASIL PENELITIAN}

Informan dalam penelitian ini 
sebanyak 12 responden dengan usia berkisar antara 30-51 Tahun. Pendidikan terakhir yang ditempuh yaitu diploma tiga dan magister. Hal ini dapat di lihat pada tabel 1.

Tabel 1. Karakteristik Informan Inti

\begin{tabular}{|c|c|c|c|}
\hline InformanInti & Umur & Pendidikan & Jabatan \\
\hline MS & 50 & S1 & Sekretaris \\
\hline AT & 51 & S1 & Kabid P2PL \\
\hline FD & 36 & S1 & Kasie P2 \\
\hline DS & 32 & S2 & $\begin{array}{c}\text { Kasubag } \\
\text { Perencanaan }\end{array}$ \\
\hline AR & 34 & S1 & $\begin{array}{l}\text { Pengelola } \\
\text { Imunisasi }\end{array}$ \\
\hline NB & 37 & S1 & $\begin{array}{l}\text { Pengelola } \\
\text { SISKOHAT }\end{array}$ \\
\hline HY & 37 & S1 & Perawat Haji \\
\hline UK & 32 & S1 & Dokter Haji \\
\hline $\mathrm{AP}$ & 37 & D3 & $\begin{array}{c}\text { Tenaga } \\
\text { Laboratorium }\end{array}$ \\
\hline YR & 35 & D3 & $\begin{array}{c}\text { Staf } \\
\text { Pelaporan } \\
\text { Haji }\end{array}$ \\
\hline SL & 30 & D3 & $\begin{array}{c}\text { Staf } \\
\text { Administrasi }\end{array}$ \\
\hline DN & 30 & D3 & $\begin{array}{l}\text { Tenaga } \\
\text { Instruktur } \\
\text { Senam }\end{array}$ \\
\hline
\end{tabular}

Standar pelayanan kesehatan haji yang dimaksud dalam penelitian ini adalah adanya petunjuk teknis yang dipedomani baik yang bersifat petunjuk teknis dan petunjuk pelaksanaan (Juknis/Juklak). Dari semua pertanyaan mengenai informasi tentang standar pelayanan kesehatan haji, rata-rata informan menginformasikan masih minimnya petunjuk pelaksanaan pelayanan kesehatan, khususnya sosialisasi prosedur pemeriksaan kesehatan haji di tingkat dasar sampai pada penentuan kesehatan bagi Jemaah haji.Seperti salah satu satu pernyataan partisipan berikut ini :

“...Kita disini melaksanakan kegiatan haji jelas ada petunjuk teknisnya, itu mi yang dipedomani, cuman jarangki disosialisasikan."

Selain itu dapat dilihat deskripsi pelaksanaan SOP Pelayanan Kesehatan di Kabupaten Mamuju pada tabel 2.

Sumberdaya yang dimaksud dalam penelitian ini adalah ketersediaan tenaga pengelola kesehatan haji dan Pengembangan pelatihan pengelola kesehatan haji di Dinas Kesehatan dan Puskesmas. Dari hasil penelitian menunjukkan saat ini pengelola kesehatan haji masih minim dan keterbatasaan ketenagaan yang terampil, bahkan sebagian dari mereka belum pernah mengikuti pelatihan tentang pelayanan kesehatan haji secara menyeluruh. Seperti ungkapan salah satu partisipan berikut :

“...Masih kurang apalagi Jemaah haji terus disini terus ada penambahan, tapi itu lagi disesuaikan juga dengan anggaran,..kan dibayar kalo ada SK-nya"

Begitu pula kurangnya pelatihan yang dilaksanakan baik ditingkat Propinsi dan Kabupaten dapat terlihat pada ungkapan informan berikut ini :

"...Iye adaji biasa pelatihan tapi masih kurang, itu pun tergantung dananya, Pak..." 
Tabel 2. Deskripsi Pelaksanaan SOP Pelayanan Kesehatan Haji Di Kabupaten Mamuju

\begin{tabular}{lcc}
\hline JenisPelayanan & \multicolumn{2}{c}{ Pelaksanaannya } \\
& Optimal & $\begin{array}{c}\text { Kurang } \\
\text { Optimal }\end{array}$ \\
\hline Menerima Calon Jemaah Haji & Optimal & - \\
Registrasi Berkas & - & Kurang \\
& & Optimal \\
Pemeriksaan Tanda-Tanda Vital & Optimal & - \\
Pemeriksaan Fisik Penujang, Penilaian Kemandirian & - & Kurang \\
dan Tes Kebugaran & & Optimal \\
Pemeriksaan Laboratorium & - & Kurang \\
Menentukan ICD-X & Optimal & Optimal \\
Mengisi Format Bantu dan Buku Follow-Up & Optimal & - \\
Pencatatan dan Pelaporan & - & Kurang \\
& & Optimal \\
\hline
\end{tabular}

Anggaran yang dimaksud dalam penelitian ini adalah pembiayaan yang dialokasi dan diperuntukkan bagi program kegiatan pelayanan kesehatan haji yang tertuang dalam Dokumen Pelaksanaan Anggaran (DPA) Dinas Kesehatan. Hasil penelitian menunjukkan bahwa biaya anggaran kesehatan haji masih sangat kurang, dan masih minimnya biaya yang diperuntukkan untuk honorarium pengelola kesehatan haji, informan menjelaskan pula bahwa tidak adanya biaya operasional dalam mengelola administrasi kesehatan haji terutama menyangkut pendataan dan pelaporan data Jemaah haji.Berikut ungkapan informan terkait penganggaran kesehatan haji :“...Kesulitan kami disini pak, tidak ada dana operasionalnya, yaa, hanya sumbangan ala kadarnya dari Jemaah, ini saja kartu rawat jalan calon Jemaah haji kami buat sendiri nda ada operasionalnya, beda dengan beberapa daerah lain pak yang sudah ada
Perda daerahnya tentang retribusi pelayanan haji."

Sarana dan Prasarana yang dimaksud dalam penelitian ini adalah fasilitas utama baik bersifat ketersediaan ruangan pemeriksaan kesehatan haji, ruangan senam kebugaran Jemaah haji, maupun fasilitas sarana penunjang seperti alat pemeriksaan laboratorium dalam pemberian imunisasi maupun pemeriksaan fisik kesehatan Jemaah haji terutama berkaitan dengan tanda-tanda vital. Hasil penelitian menunjukkan bahwa informasi informan menyebutkan bahwa masih terbatasnya ketersediaan ruangan pemeriksaan kesehatan haji bahkan, tidak adanya ruangan representative untuk pelatihan senam bagi Jemaah haji, bahkan alat untuk melaksanakan imunisasi dan pemeriksaan fisik kesehatan Jemaah haji masih kurang. Seperti ungkapan informan berikut ini :

“...ruangan dan peralatan kesehatan haji pak tentulah sangat mendukung, yaah, cumin 
begitulah pak kami disini masih sangat sederhana, untuk menginput data Jemaah sistem online saja, kami menggunakan jaringan internet, tapi terbatas jadi biasa kami nebeng di ruang perencanaan."

\section{PEMBAHASAN}

Optimalisasi pelayanan kesehatan haji sangat memungkingkan adanya penerapan standar prosedur pelayanan kesehatan haji. Hal ini dinilai penting karena Standar Operasional Prosedur adalah pedoman atau acuan untuk melaksanakan tugas pekerjaan sesuai dengan fungsi dan SOP juga merupakan alat penilaian kinerja instansi pemerintah/perusahaan berdasarkan indikator teknis, administrasif dan prosedural sesuai dengan tata kerja, prosedur dan sistem kerja pada unit kerja yang bersangkutan. Pabisangan, AW \& Horansil, ND (2011) mengungkapkan bahwa pelatihan dan penerapan SOP berpengaruh positif dan signifikan terhadap produktivitas teknisi, sedangkan reward system sertalingkungan kerja dan peralatan berpengaruh negatif dan signifikan terhadap Produktivitas Teknis. ${ }^{3}$

Dalam penelitian ini pelayanan kesehatan haji sangat dipengaruhi oleh ketersediaan dan keberadaan sumber daya tenaga pelaksana pelayanan kesehatan haji di Dinas Kesehatan maupun Puskesmas Kabupaten Mamuju. Menurut pendapat Jo Bryson (2014) mengatakan bahwa sumber daya manusia perlu ditingkatkan terus-menerus antara lain melalui pendidikan formal, non formal dan informal. Peningkatan ini dimaksudkan untuk meningkatkan kepuasan karyawan, meningkatkan kinerja mereka, mengatasi kekurangan dan meningkatkan kualitas kerja.

Tidak dapat dipungkiri bahwa ketersediaan anggaran/biaya dalam pelayanan kesehatan haji sangat mempengaruhi pencapaian keberhasilan pelayanan kesehatan haji. Dinas Kesehatan Kabupaten Mamuju telah mengalokasi anggaran pembiayaan pelayanan kesehatan haji yang tertera dalam DPA Dinas Kabupaten Mamuju, namun hanya item tertentu saja yang berupa insentif pengelola pelayanan kesehatan haji. Padahal secara keseluruhan penyelenggaraan pelayanan kesehatan memerlukan biaya operasional yang tidak sedikit. Ketersediaan anggaran paling tidak diharapkan dapat mencukupi kebutuhan program kerja pelaksanaan kegiatan yang akan dilaksanakan. Alokasi anggaran tersebut sesuai dengan kebutuhan dan peruntukkannya dan memiliki nilai-nilai keadilan dalam penyelenggaraannya. Sarana dan prasarana penunjang pelayanan kesehatan haji merupakan bagian yang tak terpisahkan dalam keberhasilan pelayanan kesehatan secara umum dan memberikan harapan tingkat kepuasan bagi jemaah dalam mengakses pelayanan kesehatan itu sendiri. Hal ini sejalan dengan pendapat Siagian (2012) bahwasanya dedikasi, kemampuan kerja, keterampilan dan niat yang besar untuk mewujudkan prestasi kerja yang 
tinggi tidak akan besar manfaatnya tanpa sarana dan prasarana yang dibutuhkan.

\section{KESIMPULAN}

Strategi pelayanan kesehatan haji adalah diperlukan adanya pedoman teknis baku/terstandar sampai kepada tingkat pelayanan di Puskesmas tentang Pelayanan Kesehatan Haji, upaya peningkatan sumber

\section{DAFTAR PUSTAKA}

1. ---------. Pelayanan Kesehatan Haji, Peraturan Menteri Kesehatan No.2407 / Menkes / Per / XII / 2011. Jakarta: Kemenkes RI; 2011.

2. Indonesian - publichealth.com.

Penyelenggaraan - kesehatan - haji

[online]. From : http://www. indonesian publichealth.com/ penyelenggaraan kesehatan-haji/ (diakses tanggal 15 September 2017)Adisasmito Wiko.Sistem Kesehatan. Jakarta: PT. Raja Grafindo Persada; 2014 (174)

3. Moleong, J. Lexy. Metodologi

Penelitian Kualitatif. Bandung: PT. Remaja Rosdakarya; 1989.

4. Notoadmodjo S. Metodologi Penelitian

Kesehatan. Cetakan Pertama. Jakarta :

Rineka Cipta; 1993.

5. Pusat Kesehatan Haji Kementerian

Kesehatan RI. Pedoman Teknis

Pemeriksaan Kesehatan Haji. Jakarta:

Kemenkes RI; 2010.

6. Sugiyono. Metode Penelitian Administrasi.

Bandung: CV. Alfabeta; 2003. daya tenaga kesehatan, penambahan alokasi anggaran yang diperuntukkan pada program dan kegiatan pelayanan kesehatan haji dan ruangan representatif bagi pemeriksaan kesehatan haji maupun ruangan untuk melaksanakan tes / senam kebugaran bagi jemaah calon haji

7. Undang - Undang Kesehatan RI, Nomor. 36 Tahun 2009,Cetakan Kedua, Jakarta : Sinar Grafika.

8. Pedoman Penyelenggaraan

Kesehatan Haji, Keputusan Menteri Kesehatan No. 442/Menkes/SK/VI/2009.

Jakarta : Kemenkes RI; 2011.

$9 . \quad$ - - Pelaksanaan Undang-

Undang Nomor 13 Tahun 2008 Tentang

Penyelenggaraan Ibadah Haji, Peraturan

Pemerintah No.79 Tahun 2012. Jakarta:

Kemenag; 2012.

10. - ------- Kesehatan Matra, Peraturan Menteri Kesehatan No. 61 Tahun 2013. Jakarta : Kemenkes RI;2013 